\title{
Hak kekayaan Intelektual pada Bisnis Pariwisata Di Kota Wisata Sungai Penuh dan Kabupaten Kerinci
}

\author{
Firya Oktaviarni $^{1 *}$, Dwi Suryahartati ${ }^{2}$ \\ ${ }^{1,2}$ Fakultas Hukum, Universitas Jambi, Indonesia \\ JL. TP. Sriwijaya Lrg. Kejayaan RT. 18 No. 18 Kel. Rawasari Kec. Alam Barajo, Jambi \\ *Correspondence email: firyaoktaviarni@unja.ac.id; dwisurya@unja.ac.id
}

\begin{abstract}
Abstrak. Kota Sungai Penuh dan Kabupaten Kerinci sebagai daerah yang mengandalkan pariwisata sebagai sumber pendapatan daerah yang didukung oleh keindahan alam dan keanekaragaman budaya masyarakat setempat. Memanfaatkan potensi alam dan budaya sebagai aset pendapatan keuangan daerah membutuhkan berbagai komponen bisnis pendukung, termasuk hotel, restoran, kuliner, biro perjalanan, seni kriya dan kerajinan, seni pertunjukan dan wisata alam dan sebagainya, dimana semua komponen ini harus dimanfaatkan secara maksimal. Termasuk keberadaan perlindungan hukum dalam bentuk perlindungan Hak Kekayaan Intelektual. Atas dasar ini, masalah hukum utama yang dianalisis dalam penelitian ini adalah penerapan Hak Kekayaan Intelektual dalam bisnis pariwisata di Kota Sungai Penuh dan Kabupaten Kerinci. Penelitian ini adalah penelitian yuridis sosiologis yang menggunakan data primer dan data sekunder sebagai bahan penelitian, dan bentuk analisis kualitatif. Hasil penelitiannya memperlihatkan keberadaan hak kekayaan intelektual di kedua daerah belum berjalan optimal karena masih banyak masyarakat yang belum memahami pentingnya keberadaan hak kekayaan intelektual sebagai bagian dari perlindungan hukum terhadap aset lokal dalam bisnis pariwisata di Indonesia. Dan pemerintah daerah dibantu dan didukung oleh akademisi harus mensosialisasikan pentingnya hak kekayaan intelektual kepada masyarakat dengan pendekatan kearifan lokal.
\end{abstract}

Kata kunci: Hak Kekayaan Intelektual; Pemerintah Daerah; Bisnis Pariwisata; Perlindungan Hukum

\begin{abstract}
The city of Sungai Penuh and Kerinci Regency rely on tourism as a source of regional income supported by natural beauties and cultural diversity of the local communities. Utilizing the potential of nature and culture as assets of regional financial income requires a variety of supporting business components, including hotels, restaurants, culinary, travel agencies, craft arts and its products, performing arts and natural tourism and so on, where all these components shall be utilized optimally. Legal protection of Intellectual Property Rights is needed as well. Based on that, the main legal problem raised in this article is the application of Intellectual Property Rights in the tourism business in the city of Sungai Penuh and Kerinci Regency. This article is sociological juridical study using the qualitative analysis method and both primary and secondary data as research materials. It is shown that the existence of intellectual property rights in both regions has not exercised optimally as there are lacks of understanding on the importance of the existence of intellectual property rights as part of legal protection for local assets in the tourism business in Indonesia. The local governments, supported by academics, shall socialise the importance of intellectual property rights to the community by using the local wisdom approach.
\end{abstract}

Keywords: Intellectual Property Rights; local government; Tourism Business; legal protection

\section{PENDAHULUAN}

Hak kepemilikan umum yang dikenal dalam ilmu hukum adalah hak atas harta benda, yaitu hak pemilikan terhadap benda yang dapat dilihat. Hak ini menjadi cabang hukum harta benda (hukum kekayaan). Disamping itu dikenal juga hak kepemilikan lainnya yaitu Hak Kekayaan Intelektual (HKI) ${ }^{1}$. Hak Kekayaan Intelektual dapat diklasifikasikan benda bergerak tidak berwujud (intangible movables) yang mula-mula dikenal di negara menggunakan sistim hukum anglo saxon (common law system). Dalam bahasa Belanda HKI termasuk sebagai benda (zaak) yang dikenal dalam hukum perdata ${ }^{2}$. Benda adalah berbagai hal yang bisa dijadikan objek hukum ataupun bisa menjadi hak bagi seseorang berdasar hukum dan mempunyai nilai ekonomi, maka bisa beralih dari pihak satu ke pihak lainnya, bisa melalui menjual dan membeli, waris, penghibahan, ataupun perjanjian khusus seperti lisensi ${ }^{3}$. Hak Kekayaan Intelektual umumnya berhubungan sebagai upaya melindungi gagasan dan data-data yang mempunyai bernilai komersil. HKI sebagai kepemilikan dan perberlakuannya dipersamakan dengan jenis-jenis kekayaan lainnya ${ }^{4}$.

Menurut pendapat Kesowo sebagaimana dikutip dalam buku Khoirul Hidayah, HKI merupakan aset yang bernilai, karena karya hasil intelektualitas dibidang ilmu pengetahuan, seni, sastra, atau teknologi lahir dengan mengorbankan tenaga, waktu, dan biaya sehingga menjadi bernilai dan berharga. Membawa dampak ekonomi yang

\footnotetext{
${ }^{1}$ Ida Bagus Wyasa Putra, Hukum Bisnis Pariwisata, PT. Refika Aditama, Bandung, 2003, hlm 107.

${ }^{2}$ Khoirul Hidayah, Hukum HKI (Hak Kekayaan Intelektual), Setara Press, Malang, 2017, hlm 2.

${ }^{3}$ Ibid.

${ }^{4}$ Tim Lindsey dkk, Hak Kekayaan Intelektual Suatu Pengantar, PT. Alumni, Bandung, 2004, hlm.3.
} 
dapat dinikmati, sehingga menciptakan konsepsi properti atas karya-karya intelektual. Dalam konsep bisnis, karyakarya tersebut disebut aset perusahaan ${ }^{5}$.

Untuk memperoleh tanda kepemilikan dari negara, untuk HKI diperlukan suatu pendaftaran. Pemahaman terhadap karya intelektual menjadi benda tidak berwujud yang dapat dijadikan aset menimbulkan kreativitas usaha. HKI merupakan benda tidak berwujud yang tidak dapat dilihat secara fisik, HKI mempunyai nilai ekonomi bagi pemiliknya dan pemilik mempunyai hak monopoli terhadap ciptaannya tersebut ${ }^{6}$.

Industri pariwisata dalam pengembangan pembangunan, dengan mendorong pertumbuhan ekonomi dalam upaya mensejahterakan masyarakat dengan orientasi pada pengembangan dan pemerataan daerah. Untuk memeratakan pengembangan daerah, terdapat beberapa aspek, yaitu sumber daya manusia, memasarkan, destinasi, ilmu pengetahuan dan teknologi, hubungan lintas sektor, bekerjasama antarnegara dan provinsi, memberdayakan usaha kecil, serta bertanggungjawab dalam memanfaatkan sumber daya alam dan budaya ${ }^{7}$.

Kegiatan berwisata, pada masa sekarang ini menjadi vital, selepas melakukan aktivitas kesehariannya mencari uang untuk memenuhi kebutuhannya. Menurut Zakaria yang dikutip M. Arief Anwar, Kepariwisataan berupa kegiatan yang dilakukan oleh seseorang dari suatu kawasan wisata, ke kawasan lainnya, bersifat sementara dan bukan mencari uang ${ }^{8}$. Dengan berwisata diharapkan mampu menghilangkan kepenatan, rasa bosan dengan aktivitas sehari-hari.

Aktivitas pariwisata yang beragam menimbulkan bergeraknya sector bisnis ditiap-tiap wilayah dan beraneka ragam investasi. Investasi mewujudkan aktivitas dengan orientasi mengembalikan investasi yang cepat dan aman. Pariwisata termasuk salah satu bidang yang menjadi tujuan investasi. Kegiatan pariwisata adalah kegiatan yang menyalurkan permintaan barang dan jasa pelayanan, seperti pengangkutan, konsultasi, konsumsi, rekreasi atraksi dan hal-hal yang berhubungan dengan kegiatan wisata ${ }^{9}$.

Pentingnya Hukum Hak Kekayaan Intelektual dalam bisnis pariwisata berhubungan dengan kenyataan dari kegiatan bisnis berwisata melibatkan berbagai komponen bisnis pariwisata seperti penginapan, rumah makan, travel, wisata tirta, wisata bahari, pantai, sungai, rafting, danau dan perairan lainnya, wisata rekreasi, wisata alam, pertunjukan, hiburan, pertunjukan, dan berbagai paket atau kemasan produk jasa pariwisata. Bidang-bidang industri lain di luar pariwisata seperti kerajinan cideramata, furniture, seni musik, patung, koreografi, arsitektur, pertunjukan, dan bagian-bagiannya, garmen, tekstil, dan lain-lain. Serta banyaknya pihak asing yang berpartisipasi dalam kegiatan pariwisata, sehingga banyak produk asing beredar di Indonesia, dan produk Indonesia beredar di luar negeri ${ }^{10}$.

Meningkatnya kegiatan bisnis pariwisata membuat kekayaan intelektual milik masyarakat Indonesia kurang mendapat perhatian. Beberapa kekayaan bahkan telah didaftarkan masyarakat asing, atau terdapat juga pelaku usaha Indonesia yang menggunakan merek dagang asing tanpa rasa salah, atau membuat merek atau kemasan produk asing. Serta kebiasaan masyarakat memproduksi atau menggunakan merek atau kemasan produk jasa secara massal, dengan kemiripan atau bahkan kemasan yang sangat sulit diidentifikasi perbedaannya ${ }^{11}$.

Provinsi Jambi merupakan provinsi yang memiliki sumber kekayaan alam yang menjadi obyek wisata, seperti halnya Kabupaten Kerinci dan Kota Sungai Penuh. Kerinci merupakan daerah yang memiliki banyak obyek wisata sehingga menjadikannya sebagai branding Pariwisata di Provinsi Jambi. Beberapa obyek wisata yang terkenal adalah Gunung Kerinci (Gunung Merapi Tertinggi di Sumatera), Danau Kaco (Danau dengan airnya berwarna biru dan jernih), Air Terjun Telun Berasap, Danau Kerinci, Air Terjun Pancuran Rayo, dan lain sebagainya. Sungai Penuh adalah wilayah pemekarandari Kabupaten Kerinci, memiliki obyek wisata yang tak kalah menarik, salah satu iconnya adalah Bukit Khayangan. Serta berbagai macam hasil kreativitas masyarakat berupa hasil olahan alam baik berupa makanan maupun minuman, tari-tarian, musik dan lagu, batik dan budaya, indikasi geografis, termasuk ekspresi foklor, dan yang lainnya menjadi daya tarik pariwisata.

Kota Sungai Penuh dan Kabupaten Kerinci adalah kawasan dengan mengandalkan pariwisata sebagai sumber pendapatan daerah yang didukung oleh keindahan alam dan keanekaragaman budaya masyarakat setempat. Memanfaatkan potensi alam dan budaya sebagai aset pendapatan keuangan daerah membutuhkan berbagai komponen

\footnotetext{
${ }^{5}$ Khoirul Hidayah, Op.Cit, hlm 3.
}

${ }^{6}$ Imas Rosidawati Wiradirja dan Fontian Munzil, Pengetahuan Tradisional \& Hak Kekayaan Intelektual (Perlindungan Pengetahuan Tradisional Berdasarkan Asas Keadilan Melalui Sui Generis Intellectual Property System), PT. Refika Aditama, Bandung, 2018, hlm 36.

${ }^{7}$ Rahman Muslim Moro Saimima dkk, Pemetaan Industri Pariwisata Maluku Sebagai Landasan Perancangan Strategi Brand "Baronda Maluku”, Jurnal Kajian Bahasa dan Pariwisata, Vol. 5 (1), (2018), hlm 88.

${ }^{8}$ M. Arief Anwar, dkk, Strategi Pengembangan Wisata Berbasis Kearifan Lokal di Kalimantan Selatan, Jurnal Kebijakan Pembangunan, Vol. 13 No. 2, (2018), hlm 189.

${ }^{9}$ Lis Julianti dan Rika Putri Subekti, Standar Perlindungan Hukum Kegiatan Investasi pada Bisnis Jasa Pariwisata di Indonesia, Kerta Wicaksana Vol. 12 No. 2, (2018).

${ }^{10}$ Ida Bagus Wyasa Putra dkk, Op.Cit, hlm 141.

${ }^{11}$ Ibid. 
bisnis pendukung, termasuk hotel, restoran, kuliner, biro perjalanan, seni kriya dan kerajinan, seni pertunjukan dan wisata alam dan sebagainya, dimana semua komponen ini harus dimanfaatkan secara maksimal. Termasuk keberadaan perlindungan hukum dalam bentuk perlindungan Hak Kekayaan Intelektual dalam bisnis pariwisata di kota Sungai Penuh dan Kabupaten Kerinci. Masalah hukum utama yang dianalisis dalam penelitian ini adalah bagaimanakah penerapan Hak Kekayaan Intelektual dalam bisnis pariwisata di Kota Sungai Penuh dan Kabupaten Kerinci?.

\section{METODE}

Lokasi penelitian dalam artikel berada di Kota Sungai penuh dan Kabupaten Kerinci. Penentuan lokasi di Kabupaten Kerinci dan Kota Sungai Penuh merupakan wilayah dengan banyak destinasi wisata. Pendekatan yang dipergunakan dalam artikel ini jenis tipe penelitian yuridis empiris, untuk mengamati peraturan yang berkaitan dengan HKI dan fakta social Bersifat deskriptif analitis, dengan mana hasil penelitian diharapkan bisa memberi gambaran tentang aspek hukum dalam pemanfaatan HKI di Kota Sungai Penuh dan Kabupaten Kerinci. Bersifat deskriptif analtis karena pengolahan data akan dianalisis secara sistematis terhadap kesenjangan antara fakta yang ada dengan ketentuan hukum yang berlaku dan memberikan gambaran keadaan objek pembahasan. Sumber data ada 2 , data primer dan sekunder. Data yang dikumpulkan baik data sekunder ataupun data primer dan diklasifikasikan dalam bentuk yuridis kemudian dianilisis secara kualitatif yaitu dengan menganalisa tanpa perhitungan sistematis atau matematis dalam bentuk pernyataan-pernyataan yang kemudian menghasilkan data yang bersifat deskriptif.

\section{HASIL DAN PEMBAHASAN \\ Konsep Hak Kekayaan Intelektual (HKI)}

HKI adalah hak kebendaan, hak atas suatu benda yang bersumber dari hasil kerja otak dan rasio. Kerja rasio manusia yang bernalar, menghasilkan benda immaterial atau benda tak berwujud ${ }^{12}$. HKI merupakan hak untuk memanfaatkan hasil ekonomi kreativitas intelektual. Objek yang diatur dalam HKI adalah suatu karya yang lahir dari kemampuan intelektual manusia ${ }^{13}$. Sistem HKI sebagai hak privat, memberikan kebebasan kepada seseorang untuk mengajukan permohonan atan mendaftarkan karya intelektualnya atau tidak, hal ini merupakan ciri khas HKI.

Dalam kerangka HKI yang dilindungi adalah haknya, bukan bentuk fisik dari karya. Bentuk fisik dari HKI tersebut dilindungi oleh hukum benda yang materil (benda berwujud). Secara garis besarnya, HKI terbagi menjadi dua, yaitu hak cipta dan hak kekayaan industri. Hak Cipta terdiri dari ilmu pengetahuan, seni dan sastra. Hak kekayaan industri terdiri dari paten, merek, desain industry, desain tata letak sirkuit terpadu (DTLST) ${ }^{14}$.

\section{Pengaturan Pariwisata}

Sesuai dengan isi dari UU Kepariwisataan, diketahui Wisata sebagai aktivitas perjalanan yang dilakukan oleh seseorang atau sekelompok orang dengan mengunjungi tempat tertentu untuk tujuan rekreasi, pengembangan pribadi, atau mempelajari keunikan daya tarik wisata yang dikunjungi dalam jangka waktu sementara ${ }^{15}$. Undang-Undang Kepariwisataan tidak mendiskriminasikan istilah wisatawan/konsumen, yang berbeda hanyalah motif pemenuhan kebutuhan wisata. Kebanyakan motif konsumen berwisata adalah motif pelepasan (escapism) dari kegiatan rutinitas berupa kegiatan bersenang-senang dengan membawa keluarga ${ }^{16}$. Artikel ini mempergunakan istilah pengunjung, pengunjung atau pelancong sebagai warga negara Indonesia yang mengadakan aktivitas perjalanan ke objek pariwisata komersial dalam waktu satu hari pulang pergi (one day trip) tidak menginap di fasilitas komersial ${ }^{17}$.

Pariwisata merupakan fenomena yang mana terjadi interaksi antara wisatawan, bisnis dan pemerintah setempat, hal ini yang menjadi daya tarik wisatawan datang ke suatu destinasi wisata ${ }^{18}$. Objek dan daya tarik wisata diklasifikasikan menjadi dua, antara lain : Pertama, objek dan daya tarik wisata ciptaan Tuhan yang berwujud keadaan alam, flora dan fauna. Kedua, objek dan daya tarik wisata hasil karya manusia yang berwujud museum, peninggalan

\footnotetext{
${ }^{12}$ OK. Saidin, Aspek Hukum Hak Kekayaan In telektual, Jakarta: PT. RajaGrafindo Persada, 2004, hlm 9

${ }^{13}$ Direktorat Jenderal Hak kekayaan Intelektual, 2006, Buku Panduan Hak Kekayaan Intelektual, Jakarta: JICA.,

${ }^{14}$ Much. NUrachmad, Segala Tentang HAKI Indonesia Buku Pintar Memahami Aturan HAKI Kita, Jogjakarta: Buku Biru,

${ }^{15}$ Pasal 1 angka (1) UU Nomor 10 Tahun 2009 Tentang Kepariwisataan.

${ }^{16}$ Yusuf Shofie, Perlindungan Konsumen dan Instrumen-Instrumen Hukumnya, Bandung: PT. Citra Aditya Bakti, 2009,
} 2003, hlm 3. 2012, hlm 22 . hlm 275 .

${ }^{17}$ https://www.researchgate.net/profile/HermansyahAndiWibowo/publication, diakses 1/11/2018.

${ }^{18}$ Ari Kusumah, Mendefenisikan Kembali Situ Mustika (Sebuat Analisis Revitalisasi Objek Wisata), Ciamis: Program Studi Ilmu Administasi Publik, hlm 48. 
purbakala, peninggalan sejarah, seni budaya, wisata argo, wisata tirta, wisata buru, wisata petualangan alam, taman rekreasi, dan tempat hiburan ${ }^{19}$.

Meningkatnya kebutuhan berwisata menarik perhatian banyak investor untuk mengelola industri pariwisata, termasuk berbagai sarana (resort), seperti hotel, tempat rekreasi, tempat hiburan (amuisement) dan lain-lain. Potensi ekonomis pariwisata lebih banyak mewarnai kebijakan pemerintah di bidang pariwisata ${ }^{20}$. Pariwisata merupakan segala macam aktivitas kewisataan dan dukungan beraneka macam fasilitas beserta pelayanan yang tersedia di masyarakat, pengusaha, Pemerintah, dan Pemerintah Daerah ${ }^{21}$. Pariwisata sesuai dengan filosofi yang terdapat dalam UU Kepariwisataan ditujukan untuk mensejahterakan masyarakat. Pariwisata merupakan sarana untuk hiburan untuk memberikan ketenangan batin masyarakat ${ }^{22}$. Pariwisata sebagai setiap kegiatan yang terkait dengan berwisata yang berkarakter multidimensi serta multidisiplin sehingga muncul sebagai perwujudan kebutuhan tiap-tiap orang dan negara serta hubungan antara wisatawan dan masyarakat sekitar, antar wisatawan, Pemerintah, Pemerintah Daerah, dan pengusaha wisata. Peran dan fungsi Pemerintah tidak dapat dilepaskan dalam mengembangkan pariwisata. Hal ini tertuang dalam Undang-Undang 23 Tahun 2014 Tentang Pemerintahan Daerah. Pengembangan pariwisata tersebut mengarah pada perpercepatan terwujudnya kesejahteraan masyarakat dengan meningkatkan pelayanan, memberdayakan dan peran serta masyarakat, beserta kemampuan saing daerah dengan memperhatikan prinsip demokrasi, pemerataan, keadilan, dan keistimewaan daerah dalam sistem Negara Kesatuan Republik Indonesia ${ }^{23}$.

Pasal 14 ayat (1) UU Kepariwisataan membagi jenis usaha pariwisata antara lain: daya tarik wisata; kawasan pariwisata; jasa transportasi wisata; jasa pejalanan wisata; jasa makanan dan minuman; penyediaan akomodasi; penyelenggaraan kegiatan hiburan dan rekreasi; penyelenggaraan pertemuan, perjalanan insentif, konferensi, dan pameran; jasa informasi; dan jasa konsultan.

Penyediaan sarana akomodasi pariwisata dalam hal ini hotel merupakan prioritas untuk menyokong pembangunan pariwisata. Untuk meningkatkan pelayanan dan menyajikan produk untuk menarik minat konsumen, maka pelaku usaha harus berkreasi dengan menciptakan layanan yang bersifat khas dan unik. Usaha penginapan berlomba-lomba memperkenalkan rencana, inovasi, maupun servis eksklusif dalam menata produk dan jasanya. Konsep perhotelan yang berkembang pada saat ini, mengemukakan konsep bermanfaat untuk lingkungan (ecofriendly approach), memberikan pelayanan pribadi (personalized service), memberikan identitas syariah, serta hal-hal lainnya ${ }^{24}$.

\section{Penerapan HKI dalam Pariwisata di Kabupaten Kerinci dan Kota Sungai Penuh}

Pariwisata di Provinsi Jambi belakangan ini mengalami perkembangan yang signifikan. Objek-objek wisata di Provinsi Jambi yang dulunya telantar dan tidak dilirik pengunjung, saat ini semakin dibenahi dan mulai memikat pengunjung. Kegiatan-kegiatan wisata di Provinsi Jambi terus bertambah sehingga memikat wisatawan untuk berkunjung ke Provinsi Jambi. Pembentukan Kabupaten Kerinci didasarkan Undang-Undang No. 58 Tahun 1958, termasuk kabupaten pusat dari beberapa Kabupaten yang ada di Provinsi Jambi. Sungai Penuh di tahun 2008 yang awalnya merupakan ibukota dari Kabupaten Kerinci dan 4 (empat) kecamatan lainnya mengalami pemekaran sebagai kota otonom dan saat ini menjadi kota madya Sungai Penuh. Batas-batas wilayah di Kabupaten Kerinci antara lain: sebelah utara berbatasan dengan Kabupaten Solok Selatan Provinsi Sumatera Barat. Sebelah selatan berbatasan dengan Kabupaten Merangin Provinsi Jambi dan Kebupaten Muko-Muko Provinsi Bengkulu. Sebelah timur berbatasan dengan Kabupaten Merangin dan Kabupaten Bungo Provinsi Jambi. Sebelah barat berbatasan dengan Kabupaten Pesisir Selatan Provinsi Sumatera Barat.

Kabupaten Kerinci adalah daerah yang dominan dalam sektor pariwisata di Provinsi Jambi dengan jargon "Sakti Alam Kerinci", yang memiliki sumber daya alam, budaya, Bahasa dan adat istiadat yng menarik minat wisatawan.

Menurut Tamara Nanayakkara, yang menyatakan bahwa:

"The tools of the intellectual property system are amply applicable to the tourism sector. Broadly speaking developng and exploiting brands is particularly appropriate to the service sector an thus to the tourism sector. Core to developing and exploiting a brand are trademarks, geographical indications (certification marks,

\footnotetext{
${ }^{19}$ Yusuf Shofie, Op.Cit, hlm 276.

${ }^{20}$ Ibid, hlm 277.

${ }^{21}$ Pasal 1 angka (3) UU Nomor 10 Tahun 2009 Tentang Kepariwisataan.

${ }^{22}$ https://www.neliti.com/id/publications/173414 diakses 4/11/2018

${ }^{23}$ Konsideran UU Pemerintahan Daerah, dikutip dalam https://www.neliti.com/id/publications/173414 diakses 4/11/2018

${ }^{24}$ Anwar Basalamah, Hadirnya Kemasan Syariah dalam Bisnis Perhotelan di Tanah Air, Binus Business Review Vol 2 No. 2
} November 2011, hlm 764. 
collective marks or a sui generis system) or industrial designs as well as other intellectual property such as patents, copyrighta and trade secrets which contribute to the whole brand image. ${ }^{25}$

Jenis Usaha Pariwisata yang ada di Kota Sungai Penuh dan Kabupaten Kerinci, antara lain:

1. Daya tarik wisata yang terdiri dari;

a. Wisata alam, seperti pegunungan, danau, air terjun

b. Wisata budaya : adat istiadat, sejarah

c. Wisata buatan seperti Depati VII Kopi

2. Jasa makanan dan minuman adalah di Kota Sungai penuh dan Kabupaten Kerinci tersedia berbagai macam restoran untuk memenuhi kebutuhan kuliner wisatawan.

3. Penyediaan akomodasi adalah tersedia 16 akomodasi berupa hotel, pondok wisata dan homestay.

4. Penyelenggaraan aktivitas hiburan setiap satu tahun sekali dengan diadakan festival danau Kerinci.

5. Wisata tirta berupa kegiatan rafting.

Jika diidentifikasikan, maka klasifikasi bentuk kekayaan intelektual dalam bisnis pariwisata, antara lain:

1. Merek dagang yang digunakan oleh hotel, restoran, dan jenis-jenis usaha jasa pariwisata lainnya;

2. Rahasia dagang, sehubungan dengan berbagai kemasan produk jasa, baik kemasan paket wisata, kompilasi data pariwisata, daftar konsumen, formula produk boga, dan minuman pada restoran dan bar-bar, dan rahasia dagang lainnya;

3. Ciptaan, seperti kebanyakan karya koreografi, lukisan, karya-karya sastra, arsitektur dan bagian-bagiannya, meubel, patung, garmen, souvenir, dan ciptaan-ciptaan lainnya, yang pada umumnya merupakan produk diluar jasa pariwisata, tetapi bersifat hubungan erat, menunjang atau bahkan sangat menentukan kekhasan atmosfir pariwisata secara keseluruhan; dan bentuk-bentuk kekayaan intelektual lainnya, termasuk desain tata letak dan sirkuit terpadu $^{26}$.

\section{Penerapan Merek dan Indikasi Geografis dalam Pariwisata}

Kabupaten Kerinci ditetapkan sebagai branding pariwisata di Provinsi Jambi. Perkataan city branding tidak dapat dilepaskan dari berbicara tentang merek, city branding serupa dengan konsep merek itu sendiri ${ }^{27}$. Recent effort to brand places also knows as "destinations branding" has at its core a trademark, whether by virtue of a registered logo or tagline. As incicated earlier branding is more than the registered logo or tagline but it is its bedrock. Also creating a fancy logo or catchy tag line is not enough for trademark purposes ${ }^{28}$.

Merek diatur dalam Undang-Undang No. 20 Tahun 2016 Tentang Merek dan Indikasi Geografis Pasal 1 angka1 UU Merek dan Indikasi Geografis, memberikan defenisi merek, yang apabila disimpulkan bahwa merek merupakan tanda yang ditampilkan dengan grafis, berupa gambar, logo, nama, kata, huruf, angka, susunan warna, bisa berbentuk dua dimensi, dan/atau tiga dimensi, suara, hologram, atau kombinasi dari dua atau lebih, suara, hologram, atau kombinasi dari 2 (dua) atau lebih unsur tersebut untuk membedakan barang dan/atau jasa yang diproduksi oleh orang atau badan hukum dalam kegiatan perdagangan barang dan/atau jasa".

Defenisi merek menurut Pasal 1 angka 5 UU Merek dan Indikasi Geografis diketahui bahwa Hak atas Merek merupakan hak yang eksklusif diberikan negara kepada pemilik suatu merek yang didaftarkan dengan jangka waktu tertentu, dan hak ini memberikan kewenangan kepada pemilik merek untuk menggunakan sendiri atau memberikan izin kepada pihak lain untuk menggunakannya. Ada beberapa jenis merek yang terdapat dalam Undang-Undang Nomor 20 Tahun 2016 yaitu merek dagang, merek jasa dan merek kolektif. Mengacu dari jenis merek tersebut, maka terkait dengan merek dodol kentang dan minuman kayu manis termasuk merek dagang dan hotel, pondok wisata, restoran.

Fungsi utama dari suatu merek adalah supaya konsumen menentukan ciri-ciri suatu produk (barang maupun jasa) yang menjadi milik suatu perusahaan sehingga bisa diklasifikasikan dari produk perusahaan lain yang serupa atau yang mirip yang dimiliki oleh pesaingnya. Terpuaskannya konsumen atas suatu produk tertentu, maka konsumen akan membeli atau memakai produk tersebut di masa yang akan datang. Penentuan terhadap produk hanya bisa dilakukan jika pemakai dengan mudah mampu produk yang asli dengan produk yang membedakan dapat melakukan hal tersebut pemakai harus mampu membedakan dengan mudah antara produki yang asli dengan produk-produk yang

${ }^{25}$ Tamara Nanayakkara, Role of Intellectual Property in enhanching the Competitivenness of the Tourism Industry, diakses tanggal 6 Juli 2019.

${ }^{26}$ Ida Bagus Wyasa Putra dkk, Op.Cit, hlm 141-142.

${ }^{27}$ Aditya Yuli, Op.Cit, hal 53.

${ }^{28}$ Tamara Nanayakkara, Op.Cit. 
identik atau yang mirip ${ }^{29}$. Indonesia menganut sistem pendaftaran atau sistem konstitutif. Apabila pendaftaran sudah dilakukan, maka undang-undang beranggapan bahwa dialah pemakai pertama dari suatu merek. Namun anggapan ini bisa berubah jika pihak lain yang berhak atas suatu merek bisa membuktikan bahwa dialah pemilik merek yang sebenarnya. Untuk penggunaan suatu merek, tidak diwajibkan seseorang mendaftarkan mereknya yang dimilikinya, namun untuk memperoleh perlindungan berdasarkan hukum merek maka ia harus mendaftarkan mereknya tersebut. Kekuatan pendaftaran merek dapat dibatalkan apabila pihak yang berkepentingan dapat membuktikan bahwa dia merupakan pemakai pertama ${ }^{30}$. They should iddeally be registered in the relevant national or regional register for trademarks and depending on a variety of factors should also be registered internationally ${ }^{31}$.

Indikasi Geografis adalah tanda untuk menunjukan daerah asal suatu barang, karena faktor lingkungan geografis termasuk faktor alam, faktor manusia, atau kombinasi dari kedua faktor tersebut, memberikan ciri dan kualitas tertentu pada barang yang dihasilkan. ${ }^{32}$ Kabupaten Kerinci memiliki Indikasi geografis yang sangat dikenal seperti teh kayu Aro, kentangnya yang dijadikan dodol, kayu manis, beras payau dan lain sebagainya. Untuk memberikan perlindungan terhadap hasil kekayaan alam yang ada di Kabupaten Kerinci diperlukan upaya perlindungan hukum berupa pendaftaran indikasi geografis yang ada didaerah tersebut. Permohonan indikasi geografis merupakan langkah strategis dalam upaya memanfaatkan Sumber daya plasma nutfah yang melimpah; mengangkat potensi wilayah dalam mengkapitalisasi sumber daya alam untuk kepentingan masyarakat serta sebagai upaya bahwa penciri suatu daerah tidak akan berpindah atau bahkan diklaim oleh pihak lain atau negara lain ${ }^{33}$.

\section{Penerapan Rahasia Dagang dalam Bisnis Pariwisata}

Rahasia dagang sebagai suatu informasi yang tidak boleh diketahui umum dalam bidang teknologi atau bisnis, serta bernilai ekonomi, dan bermanfaat untuk aktivitas usaha dan menjaga kerahasiaannya. Untuk pengaturannya ada dalam Undang-Undang No. 30 Tahun 2000. Untuk di Kabupaten Kerinci rahasia dagang selain mengenai kemasan produk jasa juga terdapat dalam makanan minuman yaitu formula pembuatan dodol kentang dan formula minuman kayu manis.

Perlindungan rahasia dagang adalah selama rahasia terjaga. Jadi, jangka waktunya tidak bisa dipastikan lama atau cepat. Rahasia Dagang mendapat perlindungan apabila informasi tersebut bersifat rahasia, mempunyai nilai ekonomi, dan dijaga kerahasiaannya melalui upaya sebagaimana mestinya. Infomasi dianggap bersifat rahasia apabila informasi tersebut hanya diketahui oleh pihak tertentu atau tidak diketahui secara umum oleh masyarakat ${ }^{34}$.

\section{Penerapan Hak Cipta (Copyrights) dalam Bisnis Pariwisata}

Hak Cipta merupakan suatu hak yang terdapat dalam ilmu pengetahuan, seni dan sastra, diwujudkan dengan bentuk yang khas dan ditampilkan dalam suatu bentuk permanen. Hak cipta sebagai hak eksklusif bagi pencipta atau yang menerima hak, bisa diumumkan atau diperbanyak ciptaannya atau mengizinkan untuk itu dengan tidak mengurangi pembatasan-pembatasan menurut peraturan perundang-undangan yang berlaku. ${ }^{35}$ Pencipta atau pemegang hak cipta, adalah orang yang memiliki hak cipta atau sesorang yang mendapatkan hak tersebut dari pencipta. Hasil dari karya seseorang yang khas dan menunjukan keasliannya dalam bidang ilmu pengetahuan, seni dan sastra disebut dengan ciptaan. Yang melingkupi hak cipta dalam bisnis pariwisata seperti budaya tradisional, pengetahuan tradisional, karya koreografi, lukisan, karya-karya sastra, arsitektur dan bagian-bagiannya, meubel, patung, garmen, souvenir, dan ciptaan-ciptaan lainnya. Untuk hak cipta dalam batik yang dilindungi adalah motifnya, seperti motif tulisan aksara incung, motif daun the dan lain sebagainya yang mencirikan Kerinci, dan ini diatur dalam Pasal 40 UUHC.

Budaya tradisional merupakan bagian kehidupan masyarakat pemilik budaya tersebut. Budaya tradisional mengandung nilai-nilai ekonomi, nilai-nilai adat (termasuk spiritual), maupun nilai-nilai komunal yang menjadi bagian masyarakat tradisional tersebut. Oleh sebab itu, terdapat keterkaitan kuat antara budaya tradisional dengan identitas masyarakat adat ditempat budaya itu hidup, tumbuh dan berkembang ${ }^{36}$.

\footnotetext{
${ }^{29}$ Karta Jayadi dan Dian Cahyadi., Buku Ajar Pengetahuan HKI "Sebuah Pengantar Memahami HKI dalam Desain", Deskomvis FSD UNM Press Program Studi Desain Komunikasi Visual Fakultas Seni dan Desain UNM, 2015 , hlm 16

${ }^{30}$ Aditya Yuli, Op.Cit, hlm 36-37.

${ }^{31}$ Tamara Nanayakkara, Op. Cit

${ }^{32}$ Mujiyono dan Feriyanto, Buku Praktis Memahami dan Cara Memperoleh Hak Kekayaan Intelektual, Sentra HKI Universitas Negeri Yogyakarta, 2017, hlm 42.

${ }^{33}$ Ibid, hlm 44.

${ }^{34}$ Ibid, hlm 47-48.

${ }^{35}$ Ibid, hlm 6.

${ }^{36}$ Affrilyanna Purba, Pemberdayaan Perlindungan Hukum Pengetahuan Tradisional dan Ekspresi Budaya Tradisional Sebagai Sarana Pertumbuhan Ekonomi Indonesia, Bandung: PT. Alumni, 2012, hlm 118.
} 
Kota Sungai Penuh dan Kabupaten kerinci memiliki budaya tradisional berupa tari-tarian. Beberapa macam kekayaan budaya yang dimiliki oleh masyarakat Kota Sungai Penuh tersebut telah ditetapkan sebagai Warisan Budaya Tak Benda yakni Rangguk Kumun, Lapeak Koto Dian, Kendiri Sko, Ntak Awo, Tari Iyo, Tari Asek dan Tale Nek Jei. Sedangkan untuk Kabupaten Kerinci Tari Ngagah Harimau dari Pulau Tengah, Tari Tauh dari Lempur, Tupai Jenjang dan lainnya. Kesenian tari tersebut termasuk ke dalam traditional knowledge. Selain tari-tarian, di kabupaten Kerinci dan Kota Sungai Penuh mempunyai foklor, ekspresi budaya yang menjadi tradisi turun temurun, peninggalan sejarah dan bersejarah. Untuk memberikan perlindungan terhadap hak cipta tersebut sudah diatur dalam Pasal 60 UUHC.

\section{SIMPULAN}

Keberadaan hak kekayaan intelektual di kedua daerah belum berjalan optimal karena masih banyak masyarakat yang belum memahami pentingnya keberadaan hak kekayaan intelektual sebagai bagian dari perlindungan hukum terhadap aset lokal dalam bisnis pariwisata di Indonesia. Pemerintah daerah dan pemerintah provinsi dibantu dan didukung oleh akademisi dalam mensosialisasikan pentingnya hak kekayaan intelektual kepada masyarakat dengan pendekatan kearifan lokal.

\section{DAFTAR PUSTAKA}

\section{Buku}

Affrilyanna Purba, Pemberdayaan Perlindungan Hukum Pengetahuan Tradisional dan Ekspresi Budaya Tradisional Sebagai Sarana Pertumbuhan Ekonomi Indonesia, Bandung: PT. Alumni, 2012, hlm 118

Direktorat Jenderal Hak Kekayaan Intelektual, 2006, Buku Panduan Hak Kekayaan Intelektual, Jakarta: JICA.

Endang Purwaningsih, 2012, Hak Kekayaan Intelektual (HKI) dan Lisensi, Bandung: CV. Mandar Maju.

Ida Bagus Wyasa Putra, 2003, Hukum Bisnis Pariwisata, PT. Refika Aditama, Bandung.

Imas Rosidawati Wiradirja dan Fontian Munzil, 2018, Pengetahuan Tradisional \& Hak Kekayaan Intelektual (Perlindungan Pengetahuan Tradisional Berdasarkan Asas Keadilan Melalui Sui Generis Intellectual Property System), PT. Refika Aditama, Bandung.

Karta Jayadi dan Dian Cahyadi., Buku Ajar Pengetahuan HKI "Sebuah Pengantar Memahami HKI dalam Desain", Deskomvis FSD UNM Press Program Studi Desain Komunikasi Visual Fakultas Seni dan Desain UNM

Khoirul Hidayah, 2017, Hukum HKI (Hak Kekayaan Intelektual), Setara Press, Malang.

Muhamad Firmansyah, 2008, Tata Cara Mengurus HaKI (Hak atas Kekayaan Intelektual), Jakarta:Visimedia.

Mujiyono dan Feriyanto, 2017, Buku Praktis Memahami dan Cara Memperoleh Hak Kekayaan Intelektual, Sentra HKI Universitas Negeri Yogyakarta.

OK. Saidin, 2004, Aspek Hukum Hak Kekayaan In telektual, Jakarta: PT. RajaGrafindo Persada.

Sulistyowati Irianto, 2012, dkk, Kajian Sosio-Legal, Pustaka Larasan, Jakarta.

Tim Lindsey dkk, 2004, Hak Kekayaan Intelektual Suatu Pengantar, PT. Alumni, Bandung.

Yusuf Shofie, 2009, Perlindungan Konsumen dan Instrumen-Instrumen Hukumnya, Bandung: PT. Citra Aditya Bakti.

\section{Jurnal}

Aditya Yuli, City Branding Sebagai Strategi Pengembangan Pariwisata Ditinjau dari Aspek Hukum Merek (Studi Kasus City Branding Daerah Istimewa Yogyakarta Sebagai daerah Tujuan Wisata Unggulan di Indonesia), Jurnal Ilmiah Ilmu Hukum QISTI Vol. 5 No. 1

Ahyani Triyana Kihin, Peran Dinas Kebudayaan, Pariwisata \& Kominfo Kota Samarinda dalam Pelestarian Budaya Adat Dayak kenyah di Kawasan Budaya Pampang, ejurnal Ilmu Pemerintahan 2013

Anwar Basalamah, Hadirnya Kemasan Syariah dalam Bisnis Perhotelan di Tanah Air, Binus Business Review Vol 2 No. 2 November 2011.

Lis Julianti dan Rika Putri Subekti, Standar Perlindungan Hukum Kegiatan Investasi pada Bisnis Jasa Pariwisata di Indonesia, Kerta Wicaksana Vol. 12 No. 2, 2018.

M. Arief Anwar, dkk, Strategi Pengembangan Wisata Berbasis Kearifan Lokal di Kalimantan Selatan, Jurnal Kebijakan Pembangunan, Vol. 13 No. 2, (2018), 189.

Rahman Muslim Moro Saimima dkk, Pemetaan Industri Pariwisata Maluku Sebagai Landasan Perancangan Strategi Brand "Baronda Maluku", Jurnal Kajian Bahasa dan Pariwisata, Vol. 5 (1), (Juli 2018), 88.

Selvi Kasman, Komodifikasi Kesenian Tradisional Wacana Estetika Posmodern dalam Pariwisata, Jurnal Ilmu Pengetahuan dan Karya Seni, Vol. 13 No. 2 Nopember 2011.

\section{Undang-Undang}

Undang-Undang Republik Indonesia Nomor 29 Tahun 2000 Tentang Perlindungan Varietas Tanaman.

Undang-Undang Republik Indonesia Nomor 30 Tahun 2000 Tentang Rahasia Dagang 
Firya Oktaviarni dan Dwi Suryahartati, Hak kekayaan Intelektual pada Bisnis Pariwisata Di Kota Wisata Sungai Penuh dan Kabupaten Kerinci

Undang-Undang Republik Indonesia Nomor 31 Tahun 2000 Desain Industri

Undang-Undang Republik Indonesia Nomor 32 Tahun 2000 Desain Tata Letak Sirkuit Terpadu

Undang-Undang Nomor 10 Tahun 2009 Tentang Kepariwisataan

Undang-Undang Republik Indonesia Nomor 28 Tahun 2014 Tentang Hak Cipta

Undang-Undang Republik Indonesia Nomor 20 Tahun 2016 Tentang Merek dan Indikasi Geografis

\section{Makalah}

Ari Kusumah, Mendefenisikan Kembali Situ Mustika (Sebuat Analisis Revitalisasi Objek Wisata), Ciamis: Program Studi Ilmu Administasi Publik, hlm 48.

Tamara Nanayakkara, Role of Intellectual Property in enhanching the Competitivenness of the Tourism Industry 